\title{
Efek Bubuk Susu Kedelai terhadap Kadar Kolesterol LDL dan HDL Serum Wanita Perimenopause dengan Hiperkolesterolemia
}

\section{The Effects of Soy Milk Powder on LDL and HDL Serum Cholesterol Levels in Hypercholesterolemic Perimenopausal Women}

\author{
Retno Kuntarti ${ }^{1}$, Sri Sukmaniah ${ }^{2}$, Sri Widia A. Jusman ${ }^{3}$ \\ ${ }^{I}$ Departemen Ilmu Gizi Fakultas Kedokteran Universitas YARSI \\ ${ }^{2}$ Departemen Ilmu Gizi Fakultas Kedokteran Universitas Indonesia \\ ${ }^{3}$ Departemen Biokimia Fakultas Kedokteran Universitas Indonesia \\ E-mail: retno.kuntarti@yarsi.ac.id
}

KEY WORDS Hypercholesterolemia, Soy milk powder, LDL, HDL

ABSTRACT Perimenopausal women is at risk of atherosclerosis as a result of the increase of LDL cholesterol level and the decrease of HDL cholesterol level. Soy milk powder consumption may protect toward these risk factors. This purpose of study is to investigate the effects of $2 \times 30 \mathrm{~g} / \mathrm{d}$ soy milk flour for eight weeks on serum cholesterol LDL and HDL levels in hypercholesterolemic perimenopausal women. The 19 subjects received $2 \times 30 \mathrm{~g} / \mathrm{d}$ soy milk powder for eight weeks. LDL and HDL serum cholesterol levels were determined at 0, 4, 9 weeks. Dietary intakes were assesed using $1 \times 24$ hours food recall. Statistical analysis used $t$ Test. After eight weeks intervention, Soy milk powder decreases significant ( $p<0.05)$ LDL cholesterol levels at the $4^{\text {th }}$ week $(8.59 \pm 17.31 \%)$, and the $8^{\text {th }}$ week $(7.81 \pm 11.32 \%)$. Soy milk powder can't increase HDL cholesterol levels at the $4^{\text {th }}$ and $8^{\text {th }}$ weeks significantly. Soy milk decrease significant the ratio of $L D L$ to $H D L(7,03 \pm 16,82 \%)$ at the $4^{\text {th }}$ week. Consuming soy milk powder $2 \times 30 \mathrm{~g} / d$ during eight weeks can reduce the LDL cholesterol level and $L D L / H D L$ ratio significantly.

\section{PENDAHULUAN}

Masa perimenopause yang umumnya dimulai pada usia akhir 40 tahun merupakan transisi dari siklus menstruasi wanita yang teratur menjadi tidak teratur dan meningkatnya periode amenorrhea (Mathai 2004; Klein 1998). Hasil sensus penduduk yang dilakukan oleh Badan Pusat Statistik (BPS) menunjukkan angka harapan hidup wanita usia lanjut mengalami peningkatan dari tahun 1980 dengan usia 54 tahun menjadi 65 tahun pada tahun 2000 . Badan Pusat Statistik juga menunjukkan jumlah usia lanjut wanita lebih banyak daripada laki-laki, yaitu sebanyak $52,42 \%$. Keadaan ini mengakibatkan masalah kesehatan yang dialami wanita di usia lanjut, seperti keluhan-keluhan yang terjadi karena menopause, dapat meningkat (Data Statistik Indonesia 2007).

Masa perimenopause terjadi penurunan produksi estrogen, menandakan berakhirnya masa reproduksi. Produksi hormon estrogen yang terus berkurang tersebut dapat menimbulkan hiperkolesterolemia 
(Mathai 2004). Penumpukan kolesterol low density lipoprotein (LDL) di dalam dinding arteri menimbulkan terjadinya fatty streak dan bila teroksidasi akan terjadi aterosklerosis. High density lipoprotein (HDL) dapat melindungi terjadinya aterosklerosis dengan membawa kolesterol dari sirkulasi kembali ke hati dan dengan mengubah kolesterol menjadi kolesterol ester dengan bantuan enzim lecithine cholesterol acyltransferase (LCAT), yang selanjutnya akan diangkut ke hati atau dipindahkan ke lipoprotein lain melalui perantara cholesterol ester transfer protein (CETP). Partikel lipoprotein tersebut akan membawa kolesterol ester ke hati (Marks dkk 2004).

Gangguan metabolisme lipid yang terjadi karena menurunnya kadar estrogen tersebut, antara lain dapat diatasi dengan terapi estrogen atau dengan pemberian makanan yang mengandung isoflavon, salah satunya adalah susu kedelai. Susu kedelai merupakan salah satu produk kacang kedelai. Dalam kacang kedelai terkandung komponen- komponen gizi yang mempunyai efek menurunkan kolesterol, seperti isoflavon, protein kedelai, asam lemak esensial dan serat, sehingga dapat membantu mengatasi peningkatan kolesterol darah pada wanita yang memasuki masa menopause (Sugano 2006; Gultekin \& Yildiz 2006).

Penelitian oleh Wangen dkk, dan Hermansen, dkk, memberikan suplementasi isoflavon masing-masing sebanyak $132 \mathrm{mg} /$ hari dan lebih dari 165 $\mathrm{mg} /$ hari bersama dengan protein kedelai menunjukkan penurunan kolesterol LDL masing-masing 6,5\% dan 10\% (Wangen dkk 2001; Hermansen dkk 2001). Zhao, dkk, 2004 yang membandingkan diet kaya lemak jenuh dan kolesterol, dengan diet kaya asam lemak esensial, menunjukkan adanya penurunan kadar LDL $12,3 \%$ pada yang diberikan diet kaya asam lemak esensial (17). Lo dan Cole memberikan serat kotiledon kedelai menunjukkan hasil penurunan LDL 7,4\%
(Zhao dkk 2004; Lo dkk 1990). Beberapa penelitian protein kedelai dengan isoflavon menunjukkan hasil tidak dapat menurunkan kadar kolesterol LDL, seperti Nikander, dkk serta Thorp, dkk (Nikander dkk 2004; Thorp 2008)

Berdasarkan latar belakang tersebut maka penelitian ini dilakukan dengan memberikan susu kedelai dalam bentuk bubuk, sebanyak 2 × 30 g/hari, dengan lama penelitian adalah delapan minggu, berdasarkan pada penelitianpenelitian sebelumnya yang memberikan protein kedelai dengan isoflavon seperti Crouse, dkk selama sembilan minggu, Hermansen yang memberikan diet perlakuannya enam minggu serta Wangen tiga kali 93 hari, selain itu dengan waktu paruh LDL tiga sampai empat hari diharapkan dengan delapan minggu tanpa pengaturan diet, sudah dapat terjadi perubahan pada kadar kolesterol (Crouse dkk 1999; Wangen dkk 2001; Hermansen dkk 2001).

Penelitian ini mempunyai tujuan untuk mengetahui apakah bubuk susu kedelai dapat membantu menurunkan kadar kolesterol LDL dan meningkatkan kadar kolesterol HDL pada wanita perimenopause sehingga dapat menurunkan risiko terjadinya aterosklerosis.

\section{METODOLOGI}

Penelitian ini merupakan suatu studi eksperimental dengan rancangan studi one-group pre-post test untuk mengetahui efek pemberian bubuk susu kedelai selama 8 minggu terhadap perubahan kadar kolesterol LDL dan kolesterol HDL pada wanita perimenopause dengan hiperkolesterolemia, dilaksanakan di Klinik Seruni Departemen Gizi FKUI dan dimulai pada bulan November 2007 sampai jumlah subyek penelitian 
terpenuhi. Subyek peneitian adalah wanita perimenopause usia antara 45-55 tahun dengan kadar kolesterol 200-239 $\mathrm{mg} / \mathrm{dL}$, indeks massa tubuh 18,5-29,9 $\mathrm{kg} / \mathrm{m}^{2}$, tidak sedang mendapatkan terapi hormonal, tidak merokok dan bersedia mengikuti penelitian dengan menandatangani informed consent. Keadaan-keadaan seperti mengonsumsi obat yang mempengaruhi metabolisme lipid atau karbohidrat, menderita diabetes melitus dengan glukosa darah puasa > $100 \mathrm{mg} / \mathrm{dL}$, fungsi ginjal terganggu dengan ureum $>43 \mathrm{mg} / \mathrm{dL}$ dan kreatinin $>0,9 \mathrm{mg} / \mathrm{dL}$, fungsi hati terganggu dengan SGOT >27 U/L dan SGPT > 34 U/L serta pernah atau sedang menderita stroke atau penyakit kardiovaskuler, akan ditolak dalam penelitian ini. Jumlah subyek penelitian minimal 20 orang. Subyek penelitian akan dilakukan penilaian asupan makanan, pemeriksaan fisik, pengukuran antropometri, serta pemeriksaan laboratorium. Penilaian asupan makanan menggunakan metode food recall 1 x 24 jam, yang dilaksanakan sebanyak lima kali, yaitu pada sebelum, awal minggu III, awal minggu $\mathrm{V}$, awal minggu VII dan awal minggu IX masa perlakuan. Selain itu, menggunakan juga pemeriksaan FFQ semikuantitatif, yang dilakukan satu kali pada sebelum masa perlakuan. Pemeriksaan ini dilakukan untuk mendapatkan data asupan makanan dari sumber kolesterol dan isoflavon selama satu bulan terakhir dengan cara menanyakan frekuensi, jumlah, jenis makanan yang dikonsumsi dengan bantuan food model. Data yang diperoleh dalam ukuran rumah tangga (URT) kemudian dikonversikan dalam ukuran gram dan sumber kolesterol diolah dengan program nutrisurvey 2005 sedangkan bahan makanan yang mengandung isoflavon diolah secara manual menggunakan daftar bahan makanan sumber isoflavon. Pemeriksaan fisik dilakukan satu kali yaitu pada awal penelitian, untuk seleksi subyek penelitian berdasarkan anamnesis, inspeksi, palpasi, dan auskultasi. Pengukuran antropometri dilakukan pada sebelum, akhir minggu IV dan awal minggu IX masa perlakuan. Pengukuran antropometri yang dilakukan meliputi berat badan (BB) dan tinggi badan (TB). Setiap pengukuran dilakukan sebanyak 2 kali dan data yang diambil adalah ratarata dari hasil pengukuran tersebut. Hasil yang didapatkan digunakan untuk menentukan Indeks Massa Tubuh (IMT). Pemeriksaan darah yang dilakukan adalah tes fungsi hati (SGOT dan SGPT), fungsi ginjal (ureum dan kreatinin), gula darah puasa, dilakukan satu kali pada sebelum penelitian, untuk menentukan kriteria penerimaan. Selain itu juga pemeriksaan kadar kolesterol LDL dan HDL yang dilakukan tiga kali yaitu sebelum, minggu IV dan awal minggu IX penelitian. Bahan penelitian yang digunakan merupakan bubuk susu kedelai yang akan diberikan kepada subyek dalam kemasan 200 gram, dan diambil oleh subyek sebanyak lima kemasan setiap dua minggu, dan masing-masing subyek mendapatkan sendok takar yang sama. Bubuk susu kedelai tersebut akan diminum 2x30 gram/hari, dengan masing-masing bubuk susu kedelai 30 gram dicampur dengan air hangat $200 \mathrm{ml}$. Kandungan nutrisi bahan perlakuan seperti pada Tabel 1.

Tabel 1. Komposisi Bubuk Susu Kedelai (per 100g bahan)

\begin{tabular}{|c|c|c|}
\hline Zat Gizi & $\begin{array}{l}\text { Kandungan Zat } \\
\text { Gizi }\end{array}$ & Satuan \\
\hline Energi & 476,0 & Kkal \\
\hline Karbohidrat & 31,5 & $\mathrm{~g} / 100 \mathrm{~g}$ \\
\hline Protein & 36,5 & $\mathrm{~g} / 100 \mathrm{~g}$ \\
\hline Lemak & 22,7 & $\mathrm{~g} / 100 \mathrm{~g}$ \\
\hline $\mathrm{Abu}$ & 3,7 & $\mathrm{~g} / 100 \mathrm{~g}$ \\
\hline Besi & 4,8 & $\mathrm{mg} / 100 \mathrm{~g}$ \\
\hline Kalsium & 410,4 & $\mathrm{mg} / 100 \mathrm{~g}$ \\
\hline Air & 5,6 & $\mathrm{~g} / 100 \mathrm{~g}$ \\
\hline
\end{tabular}

Data yang diperoleh dari seluruh pemeriksaan (wawancara asupan makanan, pemeriksaan fisik, pemeriksaan 
antropometri dan laboratorium) diolah dengan menggunakan perangkat lunak Statistical Program for Social Science (SPSS) for Windows versi 11.5. Data analisis asupan makanan ditentukan dengan program Nutrisurvey 2005, analisis asupan isoflavon menggunakan daftar bahan makanan sumber isoflavon dan dihitung secara manual dengan menggunakan kalkulator. Semua data yang ada ditabulasi dan diolah secara statisik dengan menggunakan program Statistical Program for Social Science (SPSS) for Windows versi 11.5. Data mengenai karakteristik demografi disajikan dalam bentuk deskriptif. Untuk mengetahui data yang diuji berdistribusi normal atau tidak menggunakan uji Shapiro-Wilk, dianggap normal jika $\mathrm{p}>0,05$. Jika distribusi data normal, data disajikan dalam bentuk rerata \pm simpang baku, dan jika data berdistribusi tidak normal disajikan dalam bentuk median dan rentang nilai minimum-maksimum. Analisis data numerik dua kelompok berpasangan, akan digunakan uji statistik parametrik (uji t-berpasangan) apabila data berdistribusi normal dan bila tidak berdistribusi normal akan digunakan uji statistik non parametrik (Wilcoxon). Batas kemaknaan yang digunakan pada penelitian ini adalah sebesar 5\% dengan ketentuan, tidak bermakna bila $p \geq 0,05$ atau bermakna bila $\mathrm{p}<0,05$.

\section{ISI}

\section{Karakteristik Subyek Penelitian dan Antropometrik}

Karakterisitik subyek penelitian terdiri dari karakteristik usia dan tingkat pendidikan. Rerata usia subyek penelitian $49,16 \pm 2,97$ tahun, terbanyak pada kelompok usia 50 - 55 tahun $(57,9 \%)$. Tingkat pendidikan subyek penelitian yang terbanyak adalah pendidikan rendah yaitu 10 orang $(52,6 \%)$. Karakteristik antropometrik berdasarkan indeks massa tubuh (IMT) menurut kriteria WHO untuk Asia Pasifik, didapatkan rerata IMT subyek penelitian pada sebelum penelitian (minggu 0), minggu ke-4 dan minggu ke-8 masuk kategori berisiko. Pada awal penelitian, sebanyak 8 orang $(42,1 \%)$ masuk kategori obes I, dan minggu ke-4 dan ke-8 meningkat menjadi 9 orang $(47,4 \%)$.

\section{Asupan Zat Gizi}

Pola asupan kolesterol dan isoflavon dinilai sebelum perlakuan dengan menggunakan metoda food frequency questioner (FFQ) semikuantitatif selama satu bulan terakhir, sedangkan asupan harian kalori, karbohidrat, protein, lemak, SAFA, MUFA, PUFA, kolesterol, serat dan isoflavon dinilai dengan menggunakan metoda food recall 1 x 24 jam, dan dilakukan sebanyak lima kali. Asupan energi berdasarkan KET subyek penelitian pada minggu 0 dan IV masuk dalam kategori kurang yaitu kurang dari $80 \%$, pada minggu VIII meningkat menjadi kategori cukup, antara 80-120\%. Asupan karbohidrat minggu 0 sampai dengan VIII terus meningkat, namun tetap kurang dari 50\%. Asupan protein pada minggu 0 masuk kategori kurang yaitu kurang dari $10 \%$, namun minggu IV sampai dengan VIII mengalami peningkatan menjadi kategori cukup, antara $10-15 \%$. Sedangkan asupan lemak pada minggu 0 adalah antara $20-25 \%$, termasuk kategori cukup, minggu IV dan VIII meningkat menjadi lebih dari $25 \%$, termasuk kategori lebih. Rerata asupan kolesterol subyek penelitian pada minggu 0 , IV, VII sesuai dengan yang dianjurkan, yaitu kurang dari $200 \mathrm{mg} /$ hari. Asupan SAFA minggu 0, IV dan VIII terus meningkat dan masuk kategori lebih dari yang dianjurkan, yaitu lebih dari $7 \%$. Sedangkan asupan MUFA dan PUFA subyek penelitian pada minggu 0 , IV dan VIII kurang dari 10\%, sehingga MUFA masuk kategori kurang dan PUFA cukup. 
Rerata asupan serat jauh di bawah dari yang dianjurkan, yaitu 20-30 gram/hari, baik pada minggu 0 , IV dan VIII. Rerata asupan isoflavon subyek penelitian, minggu 0 dibandingkan dengan minggu IV dan VIII mengalami peningkatan.

\section{Pemeriksaan hasil laboratorium kolesterol LDL dan HDL}

\section{Berdasarkan \\ klasifikasi}

hiperkolesterolemia NCEP-ATP III 2001

rerata kadar kolesterol LDL subyek penelitian pada minggu 0 masuk dalam kategori borderline tinggi, yaitu 134,32 \pm $23,70 \mathrm{mg} / \mathrm{dL}$. Rerata kadar kolesterol LDL pada minggu IV dan VIII terjadi penurunan yang bermakna dibandingkan dengan minggu 0 , yaitu menjadi $120,79 \pm$ $21,30 \mathrm{mg} / \mathrm{dL}$ dan $122,68 \pm 20,96 \mathrm{mg} / \mathrm{dL}$ $(\mathrm{p}<0,05)$, termasuk kategori mendekati optimal. Rerata kadar kolesterol HDL pada minggu 0 , IV dan VIII yaitu 54,95 \pm $9,88 \mathrm{mg} / \mathrm{dL}, 54,26 \pm 11,45, \mathrm{mg} / \mathrm{dL}$ dan $52,95 \pm 10,47 \mathrm{mg} / \mathrm{dL}$, masih termasuk kategori optimal (Tabel 2).

Tabel 2. Kadar kolesterol LDL, HDL serta rasio LDL terhadap HDL minggu 0,IV dan VIII serta tingkat kemaknaan

\begin{tabular}{|c|c|c|c|c|c|}
\hline \multirow[t]{2}{*}{ Variabel } & \multicolumn{3}{|l|}{ Masa Perlakuan } & \multicolumn{2}{|c|}{ Batas Kemaknaan } \\
\hline & Minggu 0 ( $n=19)$ & $\begin{array}{l}\text { Minggu } \\
(\mathrm{n}=19)\end{array}$ & $\begin{array}{l}\text { IV Minggu } \\
(\mathrm{n}=19)\end{array}$ & VIII $p^{*}$ & $p^{* *}$ \\
\hline $\begin{array}{l}\text { Kolesterol LDL } \\
(\mathrm{mg} / \mathrm{dL})\end{array}$ & $134,32 \pm 23,70$ & $120,79 \pm 21,30$ & $122,68 \pm 20,96$ & 0,01 (B) & $0,00(B)$ \\
\hline $\begin{array}{l}\text { Perbedaan } \\
\text { terhadap } \\
\text { minggu ke } 0\end{array}$ & & $-13,53 \pm 21,89$ & $-11,63 \pm 16,30$ & & \\
\hline $\begin{array}{l}\% \text { perbedaan } \\
\text { terhadap } \\
\text { minggu ke } 0\end{array}$ & & $-8,59 \pm 17,31$ & $-7,81 \pm 11,32$ & & \\
\hline $\begin{array}{l}\text { Kolesterol HDL } \\
(\mathrm{mg} / \mathrm{dL})\end{array}$ & $54,95 \pm 9,88$ & $54,26 \pm 11,45$ & $52,95 \pm 10,47$ & $\begin{array}{l}0,53 \\
\text { (TB) }\end{array}$ & 0,11 (TB) \\
\hline $\begin{array}{l}\text { Perbedaan } \\
\text { terhadap } \\
\text { minggu ke } 0\end{array}$ & & $-0,68 \pm 4,67$ & $-2,00 \pm 5,18$ & & \\
\hline $\begin{array}{l}\% \text { perbedaan } \\
\text { terhadap } \\
\text { minggu ke } 0\end{array}$ & & $-1,49 \pm 9,07$ & $-3,44 \pm 9,02$ & & \\
\hline Rasio LDL / HDL & $2,51 \pm 0,60$ & $2,29 \pm 0,47$ & $2,39 \pm 0,54$ & 0,03 (B) & 0,15 (TB) \\
\hline $\begin{array}{l}\text { Perbedaan } \\
\text { terhadap } \\
\text { minggu ke } 0\end{array}$ & & $-0,22 \pm 0,42$ & $\begin{array}{l}-0,09 \\
(-1,18-0,42)\end{array}$ & & \\
\hline $\begin{array}{l}\% \text { perbedaan } \\
\text { terhadap } \\
\text { minggu ke } 0\end{array}$ & & $-7,03 \pm 16,82$ & $-4,04 \pm 12,25$ & & \\
\hline $\begin{array}{l}\text { Keterangan: } \\
0 \text { (masa sebelum } \\
\text { berdistribusi norma } \\
\text { dalam bentuk me } \\
\text { kemaknaan }(\mathrm{p}<0,0 \\
\mathrm{TB}=\text { tidak bermakn }\end{array}$ & $\begin{array}{l}\text { rlakuan), IV (1 } \\
\text { isajikan dalam } \\
\text { n (minimum-m } \\
* \text { kemaknaan }\end{array}$ & $\begin{array}{l}\text { ke-4 perlakuar } \\
\text { rerata } \pm \text { simpan } \\
\text { m), menggunak } \\
\text { u } 0 \text { \& IV , ** }\end{array}$ & $\begin{array}{l}\text { n), VIII (awal } \\
\text { g baku, data berd } \\
\text { kan uji parametr } \\
\text { * kemaknaan min }\end{array}$ & $\begin{array}{l}\text { zu ke-9 } \mathrm{p} \\
\text { usi tidak } \mathrm{r} \\
\text { berpasan } \\
0 \text { \& VII }\end{array}$ & $\begin{array}{l}\text { uan). Data } \\
\text { al disajikan } \\
p=\text { batas } \\
\text { =bermakna, }\end{array}$ \\
\hline
\end{tabular}


Rasio kolesterol LDL terhadap HDL minggu IV dengan minggu 0 menunjukkan penurunan yang bermakna $(p<0,05), \quad$ sebesar $7,03 \pm 16,82 \%$, sedangkan antara minggu VIII dengan minggu 0 terdapat penurunan namun tidak bermakna, yaitu sebesar $4,04 \pm 12,25 \%$. Perbedaan yang tidak bermakna pada minggu VIII dengan minggu 0 , dapat terjadi karena adanya peningkatan kadar kolesterol LDL dan penurunan HDL yang lebih besar daripada minggu IV. Tabel 2, memperlihatkan rerata hasil pemeriksaan kadar kolesterol LDL, HDL, serta rasio LDL terhadap HDL pada minggu 0, IV dan VIII.

\section{Karakteristik Subyek Penelitian dan Antropometrik}

Rerata usia subyek penelitian adalah 49,16 $\pm 2,97$ tahun. Hal ini sesuai dengan Nurses Health Study Cohort yang menyatakan wanita dengan usia antara 40 sampai dengan 60 tahun mulai mengalami peningkatan kolesterol LDL sebanyak 2 $\mathrm{mg} / \mathrm{dL}$ per tahun (Welty 2002). Namun menurut Framingham study, kadar kolesterol HDL tidak terlalu mengalami perubahan. Data Framingham study juga menunjukkan risiko terkena aterosklerosis pada wanita dengan usia antara 45-64 tahun meningkat menjadi 4,5 kali dari risiko pada laki-laki dengan umur yang sama. Hal tersebut terjadi karena wanita usia 40 tahun mulai mengalami masa menopause dengan hormon estrogen yang menurun (Bassan 1999). Tingkat pendidikan subyek penelitian yang terbanyak pendidikan rendah yaitu $52,6 \%$. Hal ini sama dengan penelitian yang dilakukan oleh Juweni, 2000, yang subyek penelitiannya sebagian besar berpendidikan rendah (Juweni 2000). Subyek penelitian dengan pendidikan rendah kurang dapat mengerti pola makan yang sehat, sehingga menjadi lebih sulit dalam memberi anjuran diet. Berdasarkan kriteria WHO untuk Asia Pasifik, rerata IMT subyek pada minggu 0 , minggu IV dan VIII masuk kategori berisiko yaitu 23 - 24,9 kg/m ${ }^{2}$. Indeks massa tubuh pada subyek penelitian ini hampir sama dengan penelitian (Wangen, 2001) dengan IMT $25,2 \pm 3,6 \mathrm{~kg} / \mathrm{m}^{2}$, namun penelitian Wangen dilakukan pada wanita postmenopause, sedangkan penelitian ini pada wanita perimenopause. Berat badan lebih atau obesitas biasanya berkaitan dengan peningkatan kadar kolesterol darah sehingga merupakan salah satu faktor risiko terjadinya penyakit kardiovaskuler (Yayasan Jantung Indonesia, 2008).

\section{Asupan Zat Gizi}

Rerata asupan energi subyek pada minggu 0 adalah 58,59\%, meningkat menjadi $76,44 \%$ pada minggu IV dan 92,67\% pada minggu VIII. Asupan kalori yang tergolong dalam kategori kurang pada minggu 0 dan IV, serta cukup pada minggu VIII, tidak sebanding dengan rerata indeks massa tubuh subyek yang berkategori berisiko, sehingga kemungkinan terdapat underreported pada saat wawancara asupan sehari-hari. Kalori harus selalu dalam keadaan seimbang antara pemasukan dan pengeluaran. Pemasukan kalori yang berlebih berkaitan dengan obesitas, diabetes, hiperlipidemia dan aterosklerosis, sedangkan bila pemasukan kalori yang kurang dapat menyebabkan kaheksia (Leverve 2003). Pada penelitian ini, jumlah kalori pada awal dan pertengahan penelitian rendah. Hal ini dapat disebabkan subyek yang tidak rinci dan lengkap dalam menyebutkan jenis maupun jumlah makanan apa saja yang dimakan, pada saat diwawancara asupan diet dengan food recall 1x24 jam. Persentasi asupan karbohidrat subyek yang dibandingkan dengan KET pada minggu 0, IV dan VIII terus meningkat, namun masih tergolong kategori kurang. Asupan karbohidrat yang kurang, umumnya digantikan dengan asupan lemak yang berlebih, sehingga dapat menimbulkan risiko penyakit 
kardiovaskuler, sedangkan bila digantikan dengan asupan protein yang berlebih akan meningkatkan beban kerja ginjal (Riccardi 2003; Schlenker 2007). Rerata asupan protein subyek penelitian pada minggu 0 tergolong kategori kurang, yaitu 9,49 \pm $4,53 \%$, angka ini lebih rendah dari yang dianjurkan oleh NCEP ATP III 2001 dan PERKENI 2005. Minggu IV dan VIII asupan protein sudah sesuai dengan yang dianjurkan yaitu antara 10-15\%. Asupan protein yang baik adalah campuran antara protein hewani dan nabati. Protein kedelai berperan dalam menurunkan kadar kolesterol dalam darah, hal ini telah banyak dilakukan penelitiannya. Metaanalisis yang dilakukan oleh Anderson tahun 1995 yang memberikan 31-47 gram protein kedelai dapat menurunkan kolesterol total $9,3 \%$ dan LDL 12,9\%. Pada tahun 1999, Food and Drug Administration menyatakan diet dengan rendah asam lemak jenuh dan kolesterol serta ditambah dengan protein kedelai sebanyak minimal 25 gram/hari dapat menurunkan risiko penyakit jantung (Erdman 2001; Dewell dkk 2006). Rerata asupan lemak subyek pada minggu 0 adalah $20,55 \pm 10,65 \%$ tergolong kategori cukup, sedangkan minggu IV dan VIII mengalami peningkatan menjadi $26,20 \pm$ $7,08 \%$ dan $34,54 \pm 15,06 \%$, yang tergolong kategori lebih. Peningkatan asupan lemak minggu IV dan VIII diduga terjadi karena asupan diet yang tidak dikontrol selama penelitian, adanya penambahan asupan lemak sebanyak 13,62 gram/60 gram bubuk susu kedelai, selain itu subyek lebih banyak mengonsumsi makanan hewani daripada nabati dan yang diolah dengan digoreng. Rerata asupan SAFA subyek mulai dari minggu 0, IV dan VIII terus meningkat dan masuk kategori lebih, yaitu $8,91 \pm 5,57 \%, 10,60 \pm$ $3,36 \%$,dan $12,03 \%$ dengan nilai minimum $2,70 \%$ dan maksimum 33,26\%. Asam lemak jenuh dapat meningkatkan kadar kolesterol total dan LDL dalam darah, karena menyebabkan berkurangnya sintesis reseptor LDL, sehingga pembersihan kolesterol LDL dari sirkulasi berkurang. Penelitian yang dilakukan oleh Hu FB, dkk, 1999, membuktikan bahwa asam lemak jenuh rantai panjang berhubungan dengan meningkatnya kadar kolesterol total dan LDL, sedangkan asam lemak jenuh rantai pendek atau sedang, tidak mempengaruhi kadar kolesterol darah. Tingginya konsumsi makanan yang mengandung asam lemak jenuh, seperti daging merah dan produk susu meningkatkan risiko hiperkolesterolemia dibandingkan dengan mengonsumsi unggas, ikan dan produk susu yang rendah lemak (Riccardi 2003; Hu dkk 1999).

Rerata asupan MUFA minggu 0, IV dan VIII kurang dari yang dianjurkan oleh NCEP ATP III 2001 dan PERKENI 2005, yaitu $5,62 \pm 3,12 \%, 5,31 \pm 1,61$ dan $7,59 \pm 3,69 \%$. Rerata asupan PUFA minggu 0 juga kurang dari yang dianjurkan, sedangkan minggu IV dan VIII cukup, yaitu 4,06\%, 5,13 $\pm 2,20 \%$ dan $8,05 \pm 4,83 \%$. Monounsaturated fatty acid (MUFA) dan PUFA omega-6 mempunyai efek dapat menurunkan kolesterol total dan LDL dalam darah. Asam lemak tidak jenuh ini meningkatkan ekspresi gen reseptor LDL, sehingga kadar LDL dalam sirkulasi dapat berkurang. Efek PUFA omega-3 terhadap kadar kolesterol darah masih terdapat kontroversi, beberapa penelitian menyatakan dapat menurunkan kadar kolesterol total dan LDL, namun yang lainnya tidak dapat membuktikan. Penelitian oleh Raghu dan Venkasten, 2008 yang memberikan omega-3 dalam bentuk minyak ikan 1 gram/hari dalam kapsul selama dua minggu dapat menurunkan kadar kolesterol total $10 \%$ dan LDL 13\%. Scaefer EJ, 2002 menyatakan rasio omega 6 : omega 3 yang penting dalam mencegah penyakit kardiovaskuler adalah $4: 1$, sedangkan menurut NIH, $19992: 1-3: 1$ (Riccardi 2003; Scaefer 2002; Raghu 2008).

Rerata asupan harian serat subyek minggu 0 , IV, dan VIII lebih rendah dari yang dianjurkan oleh NCEP ATP III 2001 atau PERKENI, yaitu $6,16 \pm 3,22$ 
gram/hari, $11,83 \pm 3,16$ gram/hari dan $12,56 \pm 1,76$ gram/hari. Diet yang kaya serat, terutama serat larut, atau beberapa jenis serat yang ditambahkan dalam makanan (guar, psilium, oats, dll) dapat menurunkan kadar kolesterol LDL, namun tidak mempengaruhi kadar kolesterol HDL (Riccardi 2003). Pola asupan kolesterol subyek, telah sesuai dengan yang dianjurkan oleh NCEP ATP III 2001 dan PERKENI 2005, yaitu 155,96 $\pm 73,86 \mathrm{mg}$. Rerata asupan harian kolesterol minggu 0 dan IV juga sudah sesuai bila dibandingkan dengan anjuran, yaitu 127,80 $\mathrm{mg}$ dan $145,96 \pm 76,41 \mathrm{mg}$, namun pada minggu VIII meningkat menjadi 201,35 \pm $118,99 \mathrm{mg}$. Kecenderungan peningkatan asupan kolesterol ini diduga karena pada penelitian ini, diet sehari-hari tidak dikontrol, dengan tujuan agar hasil penelitian ini terjadi karena pengaruh bahan suplementasi susu kedelai, tanpa pengaturan diet secara ketat. Kolesterol dalam darah diperoleh dari sintesis endogen dan asupan sehari-hari, terutama telur, daging merah dan produk susu yang mengandung lemak. Makanan tersebut meningkatkan kadar kolesterol total dan LDL, terutama bila dikonsumsi dalam jumlah tinggi dan bersama dengan makanan yang mengandung asam lemak jenuh tinggi (Krauss dkk 2000). Penelitian yang dilakukan Lichtensein, dkk, 1994 yang membandingkan pemberian makanan sumber kolesterol yang ditambahkan dengan asam lemak jenuh dan asam lemak tidak jenuh sebanyak 20\% dari total kalori, yaitu 1,3 kuning telur/hari yang ditambahkan daging sapi yang berlemak dan dengan yang ditambahkan minyak jagung. Hasilnya, yang ditambahkan dengan minyak jagung, meningkatkan kolesterol LDL 8\% dan dengan daging sapi yang berlemak 11\%. Disimpulkan bahwa jenis asam lemak yang dimakan bersama dengan makanan yang mengandung kolesterol mempengaruhi besarnya peningkatan kadar kolesterol LDL. Diet yang dianjurkan adalah kolesterol $\leq 200$ $\mathrm{mg} /$ hari dengan asam lemak jenuh $<7 \%$, akan menurunkan kolesterol LDL sebanyak 15-20\% (Scaefer 2002; Lichtensein 2006). Pola asupan isoflavon subyek adalah 46,23 $\pm 73,86 \mathrm{mg}$, sedangkan asupan isoflavon minggu 0 , IV dan VIII adalah $8,20 \mathrm{mg}$, $61,45 \pm 12,46 \mathrm{mg}$ dan $66,22 \pm 22,35 \mathrm{mg}$. Bahan makanan sumber isoflavon yang sering dikonsumsi subyek adalah tahu, tempe, teh dan kacang-kacangan. Pada perhitungan asupan harian isoflavon minggu 0 , hanya menghitung nilai isoflavon yang terdapat dalam makanan yang dimakan satu hari sebelum wawancara, sedangkan pada minggu IV dan VIII menghitung juga nilai isoflavon yang didapat dari suplementasi susu bubuk kedelai. Penilaian kandungan isoflavon pada susu bubuk kedelai dihitung secara manual dengan menggunakan tabel sumber bahan makanan isoflavon COT Working Group on Phytoestrogen, tahun 2008 dan didapatkan jumlahnya $99 \mathrm{mg} / 60$ gram susu bubuk kedelai. Jumlah kandungan isoflavon pada penelitian ini lebih besar bila dibandingkan dengan kandungan isoflavon pada penelitian Juweni, 2000, yang memberikan suplementasi formula tempe yang mengandung $0,59 \mathrm{mg}$ isoflavon/100 gr. Bila dibandingkan dengan penelitian Wangen, dkk dan Hermansen, dkk yang memberikan suplementasi protein kedelai dengan kandungan isoflavon sampai dengan 132 $\mathrm{mg} /$ hari dan $165 \mathrm{mg} /$ hari, maka kandungan isoflavon pada penelitian ini lebih rendah.

\section{Pemeriksaan hasil laboratorium kolesterol LDL dan HDL}

Bubuk susu kedelai merupakan salah satu produk olahan kacang kedelai, yang mengandung beberapa komponen yang dapat mempengaruhi kadar kolesterol LDL dan HDL. Komponen tersebut diantaranya adalah protein, asam lemak esensial, serat dan isoflavon. Mekanisme protein dan isoflavon dalam menurunkan kadar kolesterol LDL berhubungan dengan sterol regulatory element binding protein 
(SREBP) yang menyebabkan terjadinya ekspresi gen reseptor LDL, selain itu, isoflavon juga mempunyai mekanisme yang lain, seperti berikatan dengan reseptor estrogen dan menjadi ligan dari peroxisome-proliferator activated receptor (PPAR) (Mullen dkk 2004). Asam lemak esensial yang ada dalam kacang kedelai adalah asam lemak tidak jenuh linoleat dan alfa-linolenat. Mekanisme kerja kedua asam lemak tersebut adalah menjadi ligan dari liver $x$ receptor (LXR) dan PPAR. Heterodimer LXR dengan RXR menyebabkan terjadinya ekspresi gen enzim cyp7a1, enzim yang mengubah kolesterol menjadi garam empedu serta transporter ABCA 1 dan ABCG 1, sebagai pembawa kolesterol keluar dari makrofag dan usus halus. Asam lemak esensial mempengaruhi PPAR sama seperti isoflavon (Torres dkk 2006; Mangelsdorf 2002). Serat kacang kedelai mengandung serat larut dan tidak larut. Serat larut ini yang berperan dalam menurunkan kolesterol, yaitu dengan mengikat kolesterol dan garam empedu. Penelitian ini menunjukkan bahwa dengan pemberian bubuk susu kedelai sebanyak 2 × 30 g/hari, dibandingkan dengan minggu 0 (sebelum mulai perlakuan), pada minggu IV dapat menurunkan secara bermakna $(p<0,05)$ kadar kolesterol LDL sebesar 13,53 \pm $21,89 \mathrm{mg} / \mathrm{dL}(8,59 \pm 17,31 \%)$ dan minggu VIII menurun sebesar $11,63 \pm 16,30$ $\mathrm{mg} / \mathrm{dL}(7,81 \pm 11,32 \%)$. Penurunan yang terjadi pada minggu VIII lebih rendah daripada minggu IV, hal ini dapat disebabkan asupan diet setiap subyek tidak diatur dan dikontrol secara ketat, terlihat dari rerata asupan kolesterol dan asam lemak jenuh yang semakin meningkat pada minggu VIII. Penurunan kadar kolesterol LDL pada penelitian ini lebih besar dibandingkan dengan penelitian Wangen, dkk, 2001, yang memberikan bubuk ekstrak protein kedelai sebanyak 85 gram/hari dengan ditambahkan isoflavon $132 \mathrm{mg} /$ hari. Hal ini dapat disebabkan oleh perbedaan pemberian suplemen, dimana pada penelitian ini memberikannya dalam bentuk bubuk kedelai, sehingga masih mengandung banyak komponen yang secara bersama-sama bekerja menurunkan kadar kolesterol LDL. Sedangkan pada penelitian Wangen, dkk, memberikan ekstrak protein sebagai komponen utamanya yang ditambahkan isoflavon, tanpa kandungan serat. Dibandingkan dengan hasil penelitian Hermansen, dkk, 2001, yang memberikan 50 gram/hari ekstrak protein kedelai ditambah dengan 20 gram/hari serat dan $165 \mathrm{mg} / \mathrm{hari}$ isoflavon, hasil penelitian ini lebih rendah. Hal ini dapat disebabkan oleh jumlah serat dan isoflavon yang terkandung dalam suplemen bubuk susu kedelai ini lebih sedikit, yaitu mengandung serat sebesar 3 gram/hari, sedangkan kandungan isoflavon sebesar $99 \mathrm{mg} / \mathrm{hari}$, yang didapat dari perhitungan berdasarkan tabel sumber bahan makanan isoflavon COT Working on Phytoestrogen, 2008. Penelitian ini menunjukkan hasil adanya penurunan pada kadar kolesterol HDL, namun tidak bermakna. Penurunan kadar kolesterol HDL pada minggu IV dengan minggu 0 adalah $0,68 \pm 4,67 \mathrm{mg} / \mathrm{dL}(1,49$ $\pm 9,07 \%$ ) dan minggu VIII dibandingkan dengan minggu 0 sebesar 2,00 $\pm 5,18$ $\mathrm{mg} / \mathrm{dL}(3,44 \pm 9,02 \%)$. Penurunan yang tidak bermakna tersebut menunjukkan dengan pemberian bubuk susu kedelai $2 \mathrm{x}$ 30 g/hari selama delapan minggu, tidak terlalu mempengaruhi kadar kolesterol HDL dan cenderung menjaga agar nilainya tetap. Hasil penelitian ini sama dengan penelitian Wangen, dkk, dan Hermansen, dkk, yang menunjukkan perubahan kadar kolesterol HDL yang tidak bermakna.

Rasio kolesterol LDL terhadap HDL minggu IV dengan minggu 0 menunjukkan penurunan yang bermakna $(p<0,05), \quad$ sebesar $7,03 \pm 16,82 \%$, sedangkan antara minggu VIII dengan minggu 0 terdapat penurunan namun tidak bermakna, yaitu sebesar 4,04 $\pm 12,25 \%$. Perbedaan yang tidak bermakna pada minggu VIII dengan minggu 0 , dapat terjadi karena adanya peningkatan kadar kolesterol LDL dan penurunan HDL yang 
lebih besar daripada minggu IV. Rasio LDL dengan HDL merupakan salah satu indikator untuk mengetahui kemungkinan terjadinya aterosklerosis, dengan adanya penurunan rasio LDL dengan HDL pada penelitian ini, risiko subyek penelitian mengalami aterosklerosis menurun. Penelitian Wangen, dkk serta Hermansen, dkk, juga menunjukkan hasil penurunan yang bermakna pada rasio kolesterol LDL terhadap HDL, yaitu sebesar $8 \%$ dan $12 \%$. Kolesterol total terdiri dari $60-70 \%$ kolesterol LDL dan $20-30 \%$ kolesterol HDL. Kolesterol LDL yang meningkat > $100 \mathrm{mg} / \mathrm{dL}$ akan meningkatkan risiko terjadinya aterosklerosis. Pada kategori mendekati optimal $(100-129 \mathrm{mg} / \mathrm{dL})$ aterogenesis sudah dapat terjadi, dan mulai kategori borderline tinggi (130 - 159 $\mathrm{mg} / \mathrm{dL}$ ) sampai selanjutnya, aterogenesis terjadi secara bermakna. Kadar kolesterol HDL yang tinggi mengurangi risiko aterosklerosis. Data epidemiologi menunjukkan adanya penurunan kadar kolesterol HDL sebesar 1\% akan meningkatkan risiko aterosklerosis sebesar $2-3 \%$. Dalam penelitian ini, kadar HDL menurun namun tidak bermakna dan masih dalam batas normal, sehingga diharapkan tidak meningkatkan risiko aterosklerosis. Beberapa faktor penyebab yang dapat menurunkan kadar kolesterol HDL diantaranya kadar serum trigliserida yang tinggi, kelebihan berat badan dan obesitas, aktivitas fisik yang kurang, merokok, asupan karbohidrat yang tinggi (> 60\% dari total kalori), penyakit diabetes tipe 2 , serta faktor genetik (Torres dkk 2006).

\section{PENUTUP}

Konsumsi bubuk susu kedelai $2 \times 30$ gram selama delapan minggu dapat menurunkan kadar kolesterol LDL serta rasio LDL/HDL secara signifikan.

\section{DAFTAR PUSTAKA}

Bassan R. Cardiovascular changes and cardiac morbidity of menopause. Effect of hormone replacement therapy. Arq Bras Cardiol 1999; 72: 92-98

Crouse JR, Morgan T, Terry JG, Ellis J, Vitollins M, Burke GL. A randomized trial comparing the effect of casein with that of soy protein containing varying amounts of isoflavones on plasma concentrations of lipids and lipoproteins. Arch Intern Med 1999; 159: 2070-2076

Data Statistik Indonesia. "Angka Harapan Hidup". Diakses tanggal 3 Februari 2007 (http://www.datastatistikindonesia.com)

Dewell A, Hollenbeck P, Hollenbeck CB.

Clinical review: a critical evaluation of the role of soy protein and isoflavone supplementation in the control of plasma cholesterol concentration. J Clin Endocrinol Metab 2006; 91: 772-780

Erdman JW. Soy protein and cardiovaskular disease: a statement for healthcare professionals from the nutrition committee of the AHA. Circulation 2000; 102: 2555-2559

Gultekin E dan Yildiz F. Introduction to Phytoestrogens. Dalam: Yildiz F editor. Phytoestrogen in Functional Foods. New York: Taylor \& Francis Group, 2006. hal 3-18.

Hermansen K, Sondergaard M, Hoeie L, Carstensen M, Brock B. Beneficial effects of a soy based dietary supplement on lipid levels and cardiovascular risk markers in type 2 diabetes subjects. Diabetes Care 2001;24: 228-233 
$\mathrm{Hu}$ FB, Stampfer MJ, Manson JE, Ascherio A, Colditz GA, Speizer FE, Hennekens CA, Willet WC. Dietary saturated fats and their food sources in relation to the risk of coronary heart disease in women. Am J Clin Nutr 1999; 70 (6): 1001-1008

Juweni. Pengaruh suplementasi formula tempe terhadap kadar malondialdehida dan F2- isoprostan pada penderita hiperkolesterolemia. Jakarta: Tesis. Program sesudah sarjana universitas indonesia. Program studi ilmu gizi klinik, 2000

Klein NA. Endocrine chages of the perimenopause. Clinical Obstetrics and Gynecology 1998; 41, 912920.

Krauss RM, Eckel RH, Howard B, Appel LJ, Daniels S, Deckelbaum LJ, Erdman JW, Kris-Etherthon P, Goldberg IJ, Kotchen T, Lichtensein A. AHA dietary guidelines: revision 2000: a statement for healthcare professionals from the nutrition committee of the american heart association. Circulation 2000; 102 : 2284-2299

Leverve XM. Integration of metabolism 1: energy. Dalam: Gibney MJ, Macdonald I, Roche HM eds. Nutrition and metabolism 1st ed. Iowa: Blackwell 2003; hal 30-42

Lichtensein A, Appel LJ, Brands M, Carnethon M, Daniels S, Franch AH, Franklin B, Kris-Etherthon P, Harris W, Howard B. Diet and lifestyle recommendations revision 2006: a scientific statement frpm american heart association nutrition committee. Circulation 2006; 114: 82-96

Lo GS dan Cole TG. Soy cotyledon fiber products reduces plasma lipids. Atherosclerosis 1990; 82: 59-67
Mangelsdorf DJ dan Zhang Y. Luxuries of lipid homeostasis: the unity of nuclear hormone receptors, transcription regulation, and cholesterol sensing. Moleculer interventions 2002; 2: 78-84

Marks DB, Marks AD, Smith CM.

Biokimia Kedokteran Dasar: Metabolisme kolesterol dan lipoprotein darah. Jakarta: EGC, 2000. hal. 512-544.

Mathai K. Nutrition in the adult years.

Dalam: Mahan LK, Escott- Stump S, editors. Krause's Food Nutrition and Diet Therapy. 11th ed. USA: Saunders, 2004. Hal 302-317.

Mullen E, Brown RM, Osborne TF, Shay NF. Soy isoflavone affects sterol regulatory element binding protein (SREBPs) and SREBP- regulated enes in hepG2 cells. J Nutr 2004; 134: 2942-2947.

Nikander E, Tiitinen A, Laitinen K, Tikkanen M, Ylirkorkala O. Effects of isolated isoflavonoids on lipids, lipoproteins, insulin sensitivity, and ghrelin in postmenopausal women. $\mathrm{J}$ Clin Endocrinol Metab 2004; 89 (7): $3567-3572$.

Raghu B dan Venkasten P. Effect of n-3 fatty acid supplementation on blood glucose, lipid profile and cytokines in humans: a pilot study. Indian Journal of clinical Biochemistry 2008; 23 (1): 85-88.

Riccardi G, Rivellese A, Williams C. The cardiovascular system. Dalam: Gibney MJ, Macdonald I, Roche HM eds. Nutrition and metabolism 1st ed. Iowa: Blackwell 2003; hal 224-246

Scaefer EJ. Lipoproteins, nutritions, and heart disease. Am J Clin Nutr 2002; 75: 191-212

Schlenker ED. Carbohydrates. Dalam: Schlenker ED, Long S eds. William's essentials of nutrition 
and diet therapy 9th ed. Philadelphia:

MOSBY Elsevier 2007; hal 29-45

Sugano M. Nutritional implications of soy.

Dalam: Sugano M, editor. Soy in Health and Disease Prevention. New York: Taylor \& Francis Group, 2006. hal 116.

Thorp AA, Howe PRC, Mori TA, Coates AM, Buckley JD, Hodgson J, Mansour J, Meyer BJ. Soyfood consumption does not lower LDL cholesterol in either equol or nonequol producers. Am $\mathrm{J}$ Clin Nutr 2008; 88 (2): 298-304

Torres N, Villalvazo IT, Tovar AR. Regulation of lipid metabolism by soy protein and its implication in disease mediated by lipid disorders. Journal of Nutritional Biochemistry 2006; 17; 6: 365-373.

Wangen KE, Duncan AM, Xu X, Kurzer MS. Soy isoflavones improve plasma lipids in normocholesterolemic and mildly hypercholesterolemic postmenopausal women. Am J of Clin Nutr 2001; 73(2): 225-231

Welty FK. Cardiovasculer disease and dyslipidemia in women. Arch Intern Med 2001; 16: 514-522

Yayasan Jantung Indonesia. Obesitas. id.inaheart.or.id. diakses tanggal 3/11/2008

Zhao G, Etherton TD, Martin KR, West SG, Gillies PJ, Kris- etherton PM. Dietary linolenic acid reduces inflammatory and lipid cardiovasculr risk factors in hyperchoesterolemic men and women. J Nutr 2004; 134: 2991-2997 